\title{
ELECTORAL REFORM AND THE PROSPECTS OF DEMOCRATIC CONSOLIDATION IN NIGERIA
}

\author{
J Shola Omotola \\ J Shola Omotola is Lecturer in the Department of Political Science \\ and Public Administration, Redeemer's University, Nigeria \\ e-mail: sholaomotola@yahoo.com
}

\begin{abstract}
The article analyses the ongoing electoral reform process in Nigeria and the prospects for the consolidation of democracy. Specifically, it explores the justifications for reform, evaluates the mechanisms adopted to promote electoral reform, notably the inauguration of the Electoral Reform Committee, its report, government's white paper on the report and the implementation of approved reform measures. Generally, the reforms have been targeted at instituting a strong election management body with substantial administrative and financial autonomy and at promoting a democratic political culture within parties and the populace. Drawing concrete insights from the 2011 Nigerian elections, which provided the first litmus test of the possible impact of the reform on the democratisation process, the article argues that while the reform process holds some promise of consolidation, it does not go far enough. Though institutional designs matter for effective electoral governance institutional reengineering without corresponding attitudinal and behavioural reform is not sufficient. The strategic decisions of the political actors, both senior and junior, to take advantage of the institutional reform process within legally permissible limits hold an important key to the restoration of credibility and public trust in the electoral process and its outcome.
\end{abstract}

\section{INTRODUCTION}

The relationship between electoral reform and public trust in electoral institutions needs to be investigated in the context of whether reform helps to increase confidence in electoral processes and outcomes and if so, under what conditions. The answer helps in determining the effect of the unprecedented discourse about 
electoral reform and the prospects of effective electoral governance and democratic consolidation in Nigeria. The study becomes more pressing given recent developments in the struggle for electoral reform geared towards the attainment of institutional and administrative autonomy for Nigeria's electoral management body (EMB), namely the Independent National Electoral Commission (INEC). As will become evident below, there are emerging signs of pervasive confidence in electoral reform, especially within civil society and the opposition parties, as possibly the ultimate solution to Nigeria's electoral dilemmas. ${ }^{1}$

If it is certainly beyond debate that Nigeria is in urgent need of electoral reform the same cannot be said about the potential impact and outcome of such a process. This is particularly the case in the light of recent Nigerian elections, which many commentators, scholars and the democracy aid industry have roundly condemned as falling below acceptable international standards (see, eg, Adebayo \& Omotola 2007, pp 201-216).

There is widespread belief, backed by intimidating evidence, that the quality of Nigerian elections nose-dives with successive elections, as was the case with the 1999, 2003 and 2007 general elections. Though longstanding, the deepening crisis of electoral governance in Nigeria has recently assumed epidemic proportions, creating an urgent need for electoral reform. Over the years Nigerian elections have offered the electorate little or no genuine choice, leading a consistent student of Nigerian politics to conclude that the history of elections in the country is one of 'electoral fraud and competitive rigging' (Ibrahim 2007, pp 2,3). This trend, as evidenced most recently in the 2007 general elections, has degenerated into a situation where results are concocted for areas where no voting actually took place. For instance, in 2007 there were reported cases of elections not being held or many registered voters being disenfranchised in several parts of the South-East and South-South. Reasons for this included violence and the non-availability, late arrival, or shortage of voting materials. Yet the regions returned full results (See, among others, The Week, 14 May 2007, pp 14-22; NDI; The Week, 17 May 2007, pp 24-28 and Tell, 7 May 2007, pp 16-29; International Crisis Group on the 2007 Nigerian Elections, 30 May 2007; Adejomobi 2007, pp 14-15 and Adebayo \& Omotola, 2007, pp 201-216.

The electoral process, from registration and the review of the voters' roll, through party primaries and election campaigns to the conduct of the elections and the handling of post- election issues (including protests and election tribunals) has often left a lot to be desired. Specifically, the review of the voters' roll was characterised by allegations of deliberate disenfranchisement of opposition

1 For a detailed analysis of Nigeria's electoral dilemmas under the Fourth Republic, see Omotola 2010, pp 535-53 and, at a more general level, starting with the colonial government, Kew 2010, pp 499-521. 
elements, for example, through an undersupply of registration kits to their perceived strongholds.

Party primaries were mere rituals, allowing no room for internal party democracy. Candidates were largely imposed by 'godfathers' and, when their scheming failed, leading to the emergence of an 'un-anointed' candidate, the godfathers resorted to substitution by elimination, using the INEC, the agency which has the overall responsibility for electoral administration in Nigeria. Its roles include registration of parties and candidates for elections and the supervision of political parties, especially in relation to finances and the conduct of elections. But the fact that it is constituted by the president, coupled with the absence of an independent source of funding and its reliance largely on the presidency for its finances means its independence is severely compromised, making it vulnerable to executive manipulation through the power of incumbency.

Despite the overwhelming justification for reform it is surprising that the notion has become very controversial in Nigeria. The controversy is partly reflected in the fact that some of the recommendations contained in the reports of Muhammed Uwais's Electoral Reform Committee (ERC), which many believed to be the archetype of genuine electoral reform, have already been voted down by the presidency and / or the National Assembly (NA). Moreover, former president Olusegun Obasanjo recently cast aspersions, covertly, on the electoral reform process, with his statement that even if Jesus Christ came to administer Nigeria's elections they would still not be free and fair (see The Nation, 2 May 2010; www. nigeriavillagesquare.com/articles / adebowale-oriku / obasanjos-retort-and-thedeath-of-imagination.html).

Will the alternative electoral architecture envisaged by the ERC yield a different level of public trust in electoral processes and outcomes? What are the sources of the pressure for electoral reform in Nigeria? In what ways may electoral reform affect popular participation (voter turnout, for example) in the electoral process? How about confidence in electoral institutions, particularly the INEC? Succinctly put, what are the likely consequences of electoral reform in Nigeria? These are the main questions this study seeks to address, with the aim of evaluating the consolidation of Nigeria's democracy.

The article explores the sources of the pressure for electoral reform; evaluates the mechanisms adopted to promote it, notably the ERC, the reconstitution of INEC, constitutional amendments, the new Electoral Act and attempts to promote internal party democracy and explores the prospects of these reform measures for democratic consolidation.

It argues that while the reform process holds some promise for consolidation it does not go far enough. Though institutional designs are important for effective electoral governance, institutional reengineering without corresponding attitudinal 
and behavioural reform is inadequate. The strategic decisions of political actors, both senior and junior, to take advantage of the institutional reform process within legally permissible limits hold an important key to the restoration of credibility and public trust in the electoral process and its outcome. Broader issues concerning the political economy of the country, particularly human security, also deserve greater attention.

\section{ELECTORAL REFORM AND PUBLIC TRUST}

The importance of electoral governance, defined as 'the wider set of activities that creates and maintains the broad institutional framework in which voting and electoral competition take place' (Mozaffar \& Schedler 2002, p 7), to democratic transition and consolidation cannot be overemphasised. Electoral governance is a comprehensive and multifaceted activity that takes place on three levels - rule-making, rule application and rule adjudication. Rule-making involves designing the basic rules of the electoral game; rule application deals with implementing these rules to specifications to organise the electoral game; and rule adjudication entails resolving disputes arising from the game. On the whole, electoral governance involves 'the interaction of constitutional, legal, and institutional rules and organisational practices that determine the basic rules for election procedures and electoral competition. It involves organising campaigns, voter registration and the vote count, resolving disputes and certifying results' (Hartlyn, McCoy \& Mustillo 2008, p 75).

In these processes 'the interplay of power structures and processes is central to electoral outcomes' (Agbaje \& Adejumobi 2006, pp 25-44). In these circumstances EMBs are part of 'a set of institutions and rules that together determine the probity of electoral processes, and in emerging democracies, where administrative processes are weak and distrust among political actors is high, their role at the centre of electoral processes tends to be more visible' (Agbaje \& Adejumobi 2006, p 76). This implies that the nature of electoral governance can contribute to democratic consolidation or regression, depending on the independence and professionalism of electoral institutions, particularly the EMB, because, 'institutional structures that promote a "level playing field" at each stage of the electoral process will enhance the extent to which voters perceive their elections to be fair' (Birch 2008, pp 305-20).

In their study of Latin America to test the importance of electoral governance to the consolidation of democracy Hartlyn, McCoy \& Mustillo (2008) established 'an important positive role for professional, independent electoral commissions on electoral outcomes', showing that 'formal-legal independence matters when the rules of the game are likely to be respected'. In addition, they found that 'low- 
quality elections occur disproportionately where incumbents seek re-election and where victory margins are extremely wide rather than narrow'.

It should, however, be noted that effective electoral governance alone does not guarantee good elections. A number of forces, including social, economic and political variables, intervene to play prominent roles in influencing the process, integrity and outcome of elections. Nevertheless, good elections are said not to be possible without effective electoral governance (Mozaffer \& Schedler 2002, p 6).

Perhaps for this reason the new focus of research in electoral studies and democratisation is gradually shifting towards electoral administration (Mozaffar 2002, pp 85-101; Elklit \& Svensson 1997, pp 32-46; Mozaffar \& Schedler 2002; Elklit 1999, pp 28-51; Elklit \& Reynolds 2002, pp 86-119; Pastor 1999, pp 1-27).

These studies demonstrate that EMBs, as the primary institutional mechanism of electoral administration, are vital to the overall quality of the electoral process, defined as 'the extent to which political actors see the entire electoral process as legitimate and binding' (Elklit \& Reynolds 2002, pp 8687). Elections are meaningfully democratic if they are free, fair, participatory, competitive and legitimate. This is possible:

when they are administered by a neutral authority; when the electoral administration is sufficiently competent and resourceful to take specific precautions against fraud; when the police, military and courts treat competing candidates and parties impartially; when contenders all have access to the public media; when electoral districts and rules do not grossly handicap the opposition; ... when the secret of the ballot is protected; when virtually all adults can vote; when procedures for organizing and counting the votes are widely known; and when there are transparent and impartial procedures for resolving election complaints and disputes.

Diamond 2008, p 25

Studies have also shown that winners and losers can accept electoral processes and results as binding provided elections are effectively administered, which is only possible if the EMB has autonomy, measured basically in terms of its structure, composition, funding and capacity (IDEA 2006). This is why one of the hallmarks of a mature democracy is a professional, independent, non-partisan election administration. However, other relevant institutions, like political parties, mass media, the security agencies and civil society groups (CSOs) are also required to play their roles effectively, including providing logistic support, which is vital to the operation of the electoral body. The oversight functions of the legislature and judiciary are also crucial. 
In Nigeria the primary responsibility for electoral administration rests with an EMB which has undergone several changes in nomenclature under different regimes, but not as many as the changes to its structure. Between 1959 and 1999 the EMB was renamed six times: Electoral Commission of Nigeria (ECN), 1959-1963; Federal Electoral Commission (FEC), 1963-1966; Federal Electoral Commission (FEDECO), 1976-1979. During the Babangida regime (1986-1993) it was renamed the National Electoral Commission (NEC). General Sanni Abacha (1993-1998) replaced the NEC with the National Electoral Commission of Nigeria (NECON), while General Abdusallami Abukakar, Abacha's successor (1998-1999) rechristened it the Independent National Electoral Commission (INEC) (Agbaje \& Adejumobi 2006, p 31). Although it has been reconstituted endlessly: in 1958, twice in 1963, in 1964, 1977, 1981, 1987, 1989, 1993, 1994, 1998, 2000 and 2004 (Browne 2004, p 39) the EMB has not been able to administer elections effectively because its 'autonomy and capacity' over the years has been suspect (Agbaje \& Adejumobi 2006, p 31).

Largely because of these shortcomings INEC has been regarded as incapable of administering Nigeria's elections effectively. Reforming it in a way that addresses these shortcomings, it is believed, would help reposition it for its Herculean task. Against this background the question of electoral reform assumes greater significance in Nigeria. Will reform engender effective electoral governance and public trust in electoral institutions, processes and outcomes? This is the main question that will be addressed in this article.

This concern is legitimate because the comparative literature on the causes and consequences of electoral reform is far from settled. Depending on which reforms have been executed electoral reforms have generally been seen to have diverse political consequences, including for participation and voter turnout, parliamentary activities, electoral processes and outcomes and trust in electoral institutions (See Green \& Gerber 2004; Johnson, Rossiter \& Pattie 2006, pp 557569).

Electoral reform, too, has many dimensions - among others reforming the electoral law, the electoral geography (eg, redrawing constituency boundaries), electoral and party systems and the EMB. In some other instances electoral reforms have been known to produce results that are both positive and negative. Specifically, Elizabeth Rigby and Melanie J Springer (2001, pp 420-34) find in their study of the consequences of electoral reform in the United States of America that 'some electoral reforms promote equality, while others further stratify the electorate, particularly when state registration rolls are already unrepresentative in terms of income groups'.

Similarly, though Ailsa Henderson (2006, pp 41-58) finds, in the case of Canada, that electoral reforms, especially those that promote proportional representation, 
may help smaller parties, increase the number of female representatives, increase turnout and improve the attitude to politics, she found no consistent evidence that electoral reforms would produce such changes. In another interesting study, Adam J Berinsky (2005, pp 471-91) concludes that electoral reform aimed at enhancing voter turnout in the USA ultimately complicated the problem by increasing socioeconomic biases in the composition of the voting public.

In Belgium, Marc Hooghe, Bart Maddens and Jo Noppe (2005, pp 351-68) found that reforms of the electoral law affect both the electoral behaviour of voters and political parties and party financing and strategy. It is partly because of this inconsistency in the consequences of electoral reform that Robert Stein, Chris Owens and Jan Leighley (2003, p 1) contend that 'the effectiveness of electoral reforms is contingent upon the strategic behavior of elites. Without strategic decisions by elites to use electoral reforms to their advantage, electoral reforms will be unrelated to voter turnout.'

Given the apparent confusion in the comparative literature about the consequences of electoral reform, which makes it difficult to generalise, it seems more rewarding to focus on specific cases, such as the ongoing reform efforts, in Nigeria.

\section{JUSTIFICATIONS AND SOURCES OF PRESSURE FOR ELECTORAL REFORM}

The main justification for electoral reform in Nigeria is rooted in the historiography of Nigerian elections, which some have characterised as a history of competitive rigging (Ibrahim 2007, pp 2-3). Indeed, throughout the various epochs of the country's political development (pre- and post-independence) electoral issues have remained, arguably, among the most influential factors in the political cycle of the country.

Over the years elections in Nigeria have lost their democratic content and relevance, due, largely, to the failure to honour the social contract between the governed and the government that elections ordinarily symbolise (Kew 2010, pp 499-521). Although electoral politics under the colonial government and in the immediate post-independence period was rooted in ethnicity, elections were, to a reasonable extent, still able to guarantee some quality and the social contract. This manifested in, for example, the existence of an 'ethnicised' but vibrant oppositional and coalition politics that is central to the good health of democracy.

This began to change during the Second Republic and the situation has been exacerbated since the criminal annulment of the 12 June 1993 presidential election. The reasons for the country's electoral misfortunes are the colonial foundation of the state, coupled with the neo-patrimonial character of its post-independence 
variant, which have served to undermine the development of the institutional architecture for effective electoral governance. These problems reached a crescendo in the aftermath of the 2007 'garrisoned' election. ${ }^{2}$

Allegations of massive irregularities marring the 2007 elections are supported by some verifiable indices. First, the results were bitterly disputed and contested in an unprecedented manner, though largely non-violently. There were 1250 petitions relating to the conduct of the elections alone - eight relating to the presidential election, 105 to the gubernatorial election, 150 to the Senate, 331 to the House of Representatives and 656 to the State House of Assembly. But when the electoral process is treated as a cycle rather than as a specific event on the day of the election the 1250 cases amount to just the tip of the iceberg.

In an astonishing revelation The Herald, a national daily, revealed on 12 May 2008 that an alarming 6180 complaints had been lodged throughout the process of the 2007 elections. Moreover, results were annulled in several states and at different levels, including the gubernatorial elections in Kogi, Edo, Kebbi, Sokoto, Adamawa, Ekiti, Osun and Ondo states. In most of these cases a rerun was mandated and, with the notable exception of Osun, was won by the ruling People's Democratic Party (PDP). In Ondo and Edo states, however, declaratory judgements were given, leading to the restoration of the electoral victories of the Labour Party and the Action Congress. The Supreme Court also reinstated the substitute candidate in Rivers State (Omotola 2010a, pp 535-553).

The main explanation for these events has been the institutional weaknesses of the EMB, most especially its lack of administrative and financial autonomy. There are three major reasons for the lack of autonomy. The first is its composition, which is the exclusive prerogative of the president. INEC is composed of a chairman, 12 national commissioners and 37 resident electoral commissioners - one for each of the 36 states of the federation and one for the Federal Capital Territory - all of whom are appointed by the federal government. This makes the INEC easily susceptible to manipulation by the president and the federal authorities. The oversight role expected of the legislature in the screening of presidential nominees for INEC positions is nullified by the fact that the president's party, the PDP, has a legislative majority to secure its wishes in Parliament (Omotola 2010a).

The second reason is the insecurity of tenure of the INEC chairman and commissioners. Security of tenure gives the leaders of an electoral commission a greater stake in securing the electoral process. If they fail to do so, they are in danger of losing their positions. Unlike in Ghana, where the chairman of the

2 A garrison democracy is one where opposition forces are permited limited or no room and the ruling party assumes a position as master of all but servant of none (Omotola 2009a). 
electoral commission and the two deputies not only have security of tenure on the same terms and conditions of service as judges of the Court of Appeal, which means they cannot be removed arbitrarily until they retire at age 70 (Omotola 2009b, pp 42-64; Agyeman-Duah 2005, p 3), Nigerian electoral officials statutorily occupy the office for five years, renewable for a further term.

They can, however, be removed by the president on flimsy grounds. This was the fate of two successive electoral commission chairmen under Babangida, namely professors Eme Awa and Humphrey Nwosu, who were removed from office in 1989 and 1993 respectively in questionable circumstances. The former was removed because of his uncompromising stance on the management of the electoral commission and the latter following the military government's decision to annul the 12 June 1993 presidential elections against the wishes of the electoral commission (Nwosu 2008).

The third issue relates to the funding of the electoral body (Omotola 2009a, pp 195-221). Ordinarily an independent EMB should be funded directly from the consolidated account, thereby limiting the extent of financial control the executive can exert over it. In Nigeria, however, this is not yet the case. Under the current regime the INEC does not have an independent budget or sources of funding. Rather, it depends almost entirely on the presidency to fund its activities. This allows the presidency considerable financial control over the body, contributing to its inability to make adequate, timely plans and preparations for successive elections.

INEC has also been severely constrained with respect to capacity. Two primary indicators of this are the appointment of people without professional and intellectual competence to man the body. For instance, Professor Maurice Iwu, the immediate past chairman, has neither professional nor intellectual experience in electoral management - he was trained in the health sciences.

The second is INEC's reliance on the use of ad hoc staff, who are usually partially briefed for a day on their duties. After every flawed election INEC tends to place most of the blame on these temporary employees (Iwu 2008).

Worse still, INEC reflects the centrist proclivities of the federal democracy, with its over-centralisation of power. The most visible evidence is that it responsible for the administration of all federal elections (presidential and National Assembly) and state elections, including gubernatorial and state houses of assembly in the 36 states of the federation. The only responsibility assigned to state independent electoral commission (SIECs) is the administration of local government elections. As a result of these institutional constraints it has been difficult for INEC to govern the electoral processes effectively in order to produce credible elections whose outcomes will be acceptable to all political players, or at least a majority of them. 
This is not to say that the only motivation for reform was the need to reposition the EMB for effective electoral administration. Other election-related institutions, particularly political parties, have also been a very weak link in the electoral processes of the country (Omotola 2009c, pp 612-634; Omotola 2010b, pp 125-145; Adejumobi \& Kehinde 2007, pp 95-113).

Some of the notable limitations of political parties in Nigeria include their weak ideological foundations, which induce them to mobilise on the bases of identity, particularly ethnicity and religion, and, more importantly, the lack of internal party democracy, which fuels a culture of impunity, indiscipline, intraparty squabbles and political vagrancy. These shortcomings are known to be the core underpinnings of electoral corruption and violence in the country (Omotola 2010c, pp 52-73).

Essentially, the pressure for electoral reform has largely been from within, with opposition political parties, civil society organisations and the electorate the leading voices. Leading opposition parties, particularly the Action Congress of Nigeria (CAN) and the All Nigeria Peoples Party (ANPP) were upset about the fact that INEC's ineffectiveness undermined their efforts by conferring undue advantage on the ruling PDP. Pro-democracy activists and civil society groups were also determined to ensure the establishment of a capable EMB to conduct free, fair and credible elections in which the votes would actually count.

For example, during its protest about the crisis relating to the health of President Umaru Yar'Adua (who later died in office) (Omotola 2011, pp 222253) and the National Assembly's refusal to make then-Vice-President Goodluck Jonathan acting president, one of the three demands of the Save Nigeria Group (SNG), a coalition of civil society groups and democracy and human rights

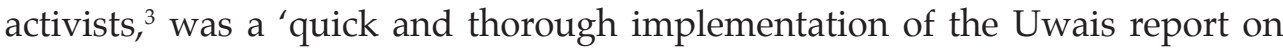
reform, starting with the immediate removal of Professor Maurice Iwu as chairman and the reconstitution of INEC with persons of impeccable integrity and competence' (Agbo 2010, pp 32, 34).

\section{THE REFORM PROCESS AND THE 2011 ELECTIONS}

The electoral reform process in Nigeria has mainly been built on fostering the independence of the EMB and promoting a democratic political culture within political parties. The essence is to evolve a strong institutional basis of politics

3 Among the notable members of the SNG are Professor Wole Soyinka, Nobel Laureate; Femi Falana, a radical lawyer; Pastor Tunde Bakare, founder of the Latter Rain Assembly; Rotimi Akeredolu, president of the Nigerian Bar Association; Balarabe Musa, former governor of Kaduna state and chairman of the Conference of Nigerian Political Parties; Pat Utomi, a renowned economist, and Ayo Obe, a former president of the Civil Liberties Organisation. 
capable of governing the electoral process effectively and regulating the behaviour of political actors. This is understandable because one of the main limits of effective electoral governance in Nigeria over the years has been the gross lack of institutional autonomy for the EMB and the absence of internal party democracy, as illustrated above.

The reform process began with the inauguration of a 23-person Electoral Reform Committee (ERC) on 28 August 2007, with a comprehensive mandate 'to evolve an electoral process that will enable us to anchor democracy as the framework for national integration, sustained growth and national development' (Yar' Adua 2007). The ERC consists of some notable and credible Nigerians, with former Chief Justice Muhammed Uwais as its chairman and representatives of diverse interests, including civil society, mass media, academia, women's groups, trade unions and professionals.

In fulfilling its mandate the ERC conducted public hearings around the country, in the process collating memoranda from diverse stakeholders. Specifically, the committee received a total of 1466 memoranda from the general public. It also held public hearings in two capital cities in each of the six geopolitical zones and the Federal Capital Territory, during which a total of 907 presentations was made (the report was submitted to President Yar'Adua shortly before his death). This created the impression that not only does the ERC enjoy some level of autonomy, which is important for the effectiveness of its activities, but also that the government seems genuinely to intend to reform the electoral process.

The ERC made important recommendations that would not only guarantee INEC's autonomy, it also suggested options for ensuring a system in which internal party democracy will thrive. Specifically, the committee recommended the establishment of a new, truly non-partisan independent and impartial INEC comprising a chairman, deputy chairman and six members of unquestionable integrity, one of whom must come from each of the six geopolitical zones.

In addition, it recommended the inclusion of six further nominees - one from each of organised labour, the Nigerian Bar Association, the media, the National Youth Council, civil society and women's organisations. All the appointments will be subject to Senate confirmation.

It is recommended that the chairman be appointed in an open and transparent process, with the National Judicial Council advertising the position, spelling out the requisite qualifications, receiving applications or nominations from the general public, short-listing three people for each position and sending the nominations to the National Council of State which will select one for each position and forward the names to the Senate for confirmation.

More importantly, the ERC recommended that INEC be funded directly 
from the Consolidated Revenue Fund in order to guarantee its financial and administrative independence.

With respect to the conduct of the elections the ERC suggested an open secret ballot system which allows voters to mark their ballots in secrecy and drop them in boxes in the open, as well as the accreditation of registered voters prior to the commencement of voting for the purpose of tracking the number of people who vote at a particular polling station.

The ERC also recommended that the voters' register be displayed prior to the elections to enable registered voters, political parties and the electorate generally to make claims and lodge objections, and that elections results should be announced at all polling centres by presiding officers, be signed and copies be given to accredited agents, the police and the State Security Service (SSS), the intelligence arm of the federal security apparatuses.

In order to obviate situations where winners whose victory has been contested assume office and deploy state resources to prosecute cases brought against them the ERC recommended that all objections be dealt with before winners are sworn in. This may have informed the recommendation that all electoral petitions be dealt with up to the highest level of appeal within a maximum period of six months (four for the tribunal, two for the appeal). It also recommended that provision be made for independent candidates.

Other important recommendation from the ERC were:

- the establishment of a Political Parties Registration and Regulatory Commission (PPRRC) to, among other things, register political parties, monitor their organisation and operations and arrange for the annual auditing of accounts;

- the establishment of an Electoral Offences Commission (EOC) to, among other things, deter the commission of electoral malpractice, investigate where it occurs and prosecute alleged offenders;

- the establishment of a Centre for Democratic Studies (CDS) to undertake broad civic and political education of legislators, political office holders, security agencies, political parties and the general public.

These recommendations were hailed by civil society groups and opposition political parties as capable of laying the foundations not only for an independent and a more effective INEC, but also for the consolidation of democracy. However, the initial euphoria soon began to wane as the government dragged its feet about making official pronouncements on the committee's recommendations (IFES).

By the time the Federal Executive Council (FEC) did respond its white paper 
further dampened popular expectations. Among the recommendations the FEC rejected were that the NJC should appoint INEC's chair, the deferment of the swearing in of elected persons until the courts have fully disposed of petitions against them, and the shifting of the onus of proof to INEC. Instead, the FEC insisted that the INEC chairman be appointed by the president, that those elected should be sworn in as soon as the winner is announced and that the onus of proof should remain with the petitioner.

The rejection of these crucial recommendations raises questions about government's commitment to a fundamental reform of the electoral process. ${ }^{4}$ Opposition parties, notably the Action Congress (AC), now Action Congress of Nigeria; the All Nigeria People Party; the Democratic Peoples Alliance (DPA); and the Conference of Political Parties (CNPP), the umbrella body of opposition parties; as well as leading civil society groups, including the Nigerian Labour Congress (NLC), the Alliance for Credible Election (ACE), the Transition Monitoring Group (TMG), the Electoral Reform Network (ERN), the Citizen's Forum for Constitutional Reform (CFCR), the Gender for Constitutional Reform Network (GCRN) and the National Coalition on Affirmative Action (NCAA), all spoke against the rejection (see Akintude 2008).

In spite of the popular outcry that attended the release of the white paper the government proceeded with the reform process. The first major step was the appointment of Professor Attahiru Jega, a respected political scientist and democracy activist, as chair of INEC, a decision that was positively received. ${ }^{5}$ INEC's financial autonomy was guaranteed by the fact that its funding will come directly from the consolidated funds, which allows it to prepare its budget and defend it before Parliament.

With these two important changes made INEC was able to commence preparation for the elections, beginning with the voter registration exercise. The exercise was characterised by a number of irregularities, for example, the unavailability of an imported data-capturing machine and sundry logistical problems such as power failures, malfunctioning machines, particularly their inability to capture fingerprints, which bedevilled its early stages. Most of these were rectified as the exercise progressed and the relative speed with which INEC secured the release of funds for the registration process would have been unthinkable without the reforms. In addition, within a remarkably short time the

4 The Electoral Reform Network, a coalition of more than 100 civil society groups committed to the reform and promotion of credible elections in Nigeria, alluded to this fact at its National Civil SocietyLegislative Consultative Forum held at the National Assembly Complex, Abuja, on 15 September 2009. See www.electoralreformnetwork.org/news_details.php?news_id=17.

5 Jega was national president of the Academic Staff Union of Universities during the Babangida regime. He was credited with a solid performance, especially in his rejection of all attempts to win him over to the side of the military junta. 
Senate had approved the N87 721961531 requested by INEC for the 2011 general elections (www.nigerianelitesforum.com).

These moves were closely followed by changes in the composition of INEC's national and resident electoral commissioners. Up to that point only four of the required 12 national commissioner positions were occupied, which many considered inappropriate. Still, civil society groups and opposition parties were unhappy for two reasons - some members of the reconstituted INEC were cardcarrying members of political parties, which could compromise their neutrality and some members of the highly discredit Maurice Iwu's INEC, which had given the country the worst elections in its political history, were retained (the tidenewsonline.com). Both the president and the INEC chairman promised to investigate the allegations and, if necessary, make changes. This never happened, either because of time constraints or because of the absence of political will to follow through on the reform effort.

Some of the proposed reform initiatives required constitutional amendments. This necessitated a review of the Electoral Act of 2006 and the 2010 Electoral Act was adapted to accommodate the changes, for example, the new order/ sequencing of elections, as well as a provision banning floor crossing - candidates who change parties once they are elected will have to forfeit their seats and stand for election again under the banner of their new party.

Despite considerable criticism at every stage of the reform process the effort would appear to have made some positive impact on the overall administration of the elections. This is particularly the case at the level of voting and the counting of results. The reports of international and local election observers were unanimous in declaring the 2011 Nigerian elections a significant improvement on those of 2007.6

Although all observed that the elections were generally conducted in a peaceful atmosphere there were some notable reservations. In many places materials and officials arrived late; in some states there were many underage voters; there was political violence and ballot box snatching and stuffing - there were several cases of people being arrested with sizeable quantity of ballot papers on the eve of the presidential and gubernatorial elections in many parts of the country. INEC claimed they were contractors charged with producing dummy ballot papers. ${ }^{7}$

6 For a representative excerpt from the reports of the various monitoring groups on the presidential election, see 'International Observers Comment on Nigeria's Elections'. Available at: sahelblog. wordpress.com/2011/04/20/international-observers-comment-on-nigerias-elections / For The European Union Election Observation Mission's final report see www.eueom.eu / files / pressreleases / english / final-report-nigeria2011_en.pdf.

7 See 'PDP Chieftain Arrested in Eket as SSS Seals off Printing Press for Alleged Printing of Ballot Papers'. Available at: www.osundefender.org/? $\mathrm{p}=14670$ 
Most importantly, there were alleged manipulations and inflation of votes for the ruling PDP at collation centres, practices that were reportedly rampant during the presidential election of 16 May in the South-East and the South-South, two zones regarded as strongholds of incumbent president Jonathan Goodluck. The two leading opposition parties, the Action Congress of Nigeria (ACN) and the Congress for Progressive Change (CPC), for example, complained bitterly about what they called magic numbers. The CAN stated:

... An analysis of the results put out by INEC itself has shown a troubling pattern of clear manipulation. Everywhere the PDP perceived it was strong, it came out with incredibly high numbers of votes in his favour. Conversely, anywhere the opposition was perceived to be strong, the opposition's margin of victory was unreasonably low.

Osun Defender, April 20118

A few examples will suffice:

- In both the South-South and South-East, where President Jonathan is believed to have strong support, the average turnout was 67 per cent, compared to 32 per cent for the South-West, where there is believed to be a strong opposition.

- In the North-West and North-East, which are considered bastions of opposition, the average turnout of registered voters was 54 per cent.

And whereas high voter turnout was recorded in states perceived to be sympathetic to President Jonathan in the different geopolitical zones (Bayelsa in South-South $85 \%$, Imo in South-East 84\%, and Plateau in North-Central 62\%), the opposite was the case in areas where the opposition, was believed to be strong. Even in Katsina, in the North-West, the hometown of General Mohammadu Buhari, Goodluck Jonathan's CPC opponent in the presidential election, the turnout was a paltry 52 per cent. The story was much the same in Kano (53\%), Sokoto (40\%) and Zamfara (51\%).

It is also instructive that even though Edo state is in the South-South, the turnout was only 37 per cent, apparently since the figure cooks did not believe the state to be sympathetic to President Jonathan because it was controlled by the ACN. The turnout figures for the South-West are also revealing: Lagos (31.8\%), Ogun (28\%), Osun (39\%) and Oyo (33\%).

8 These allegations constitute the bases of petitions by the CPC against Jonathan's presidential victory, which are yet to be proved at the electoral tribunal, but are ongoing. 
Also, while the margin of victory for the PDP in the South-South was 98\% and for the South-East $98.9 \%$, the highest margin of victory for the CPC in the North-West was 55.8\%.

These allegations, however, remain to be proved beyond reasonable doubt. The CPC has already filed a petition asking for the ballot papers from these zones be subject to forensic analysis. Until the outcome of the analysis the allegation remain what they are, mere allegations.

\section{CONCLUSION: ELECTORAL REFORM AND THE PROSPECTS OF DEMOCRATIC CONSOLIDATION}

There has been no scientific interrogation of the impact of the electoral reform process on the level of public trust in the electoral institutions, the electoral processes and the outcomes, thus only tentative conclusions can be drawn, relying on the reports of election observers, both local and international, as well as the personal observations of the researcher and media reportage on the elections.

Judging from these sources there seems to be widespread belief that the conduct of the 2011 elections was a significant improvement on that of any election since 1999. ${ }^{9}$ Notable areas where the improvement manifested itself include voters' enthusiasm not only about participating but about policing the elections to ensure that their votes counted; the adoption of a modified 'Option A4', which reduced the possibility of manipulation of results, at least openly, at the voting booths; and the announcement and placement of results on notice boards at the voting and result collation centres, which gave interested parties the opportunity to tabulate the votes. ${ }^{10}$

Despite these advances there were notable reservations about the democratic qualities of the elections in terms of competitiveness, participation and legitimacy. For instance, there were allegations that the playing field was not level. A few examples illustrate this:

- The PDP reportedly prosecuted its elaborate presidential campaigns relying heavily on state resources, especially the presidential jets.

9 Preliminary reports by the European Union, the National Democratic Institute, the Commonwealth, the African Union and local monitoring groups made this clear. For representative views, see 'International Observers Comment on Nigeria's Elections'. Available at: sahelblog.wordpress.com/2011/04/20/ international-observers-comment-on-nigerias-elections /

10 Option A4 is a method of voting originally introduced by Humphrey Nwosu, then electoral umpire of the country, during the transition to the aborted Third Republic in 1992-93, which 'had voters meet within a designated time frame on election day and line up behind the party standard for which they wished to vote, and then a single count of all the votes would be taken in plain sight of the community in question' (Kew 2010, p 505). 
- There were unsubstantiated allegations that the PDP also deployed a whopping N107-billion (about \$16 050-million) within three days to the presidential election to buy votes, the lion's share of which was reportedly allocated to the northern part of the country, considered to be the stronghold of the opposition CPC. ${ }^{11}$

To date the PDP has not rebutted these allegations.

- The media landscape was also disproportionately skewed in favour of the PDP, contrary to the provision of the Electoral Act of 2010, which stipulates that media time shall be allocated equally among political parties and candidates. For instance, the European Union Election Observation Mission (EUEOM) noted in its preliminary statement about the election that:

the state-owned Nigerian Television Authority (NTA) lacked balance towards the candidates. Only 21 parties and their representatives were mentioned during the NTA prime time. 80 percent of the coverage allocated to the political actors was devoted to PDP, five percent to ACN and CPC each, and ANPP gained a three percent. Twelve out of the 20 presidential candidates were mentioned during the NTA prime time. With regard to direct speech in the NTA news bulletins, 75 percent of it was dedicated to the incumbent President Jonathan.

Worse still, the elections were characterised by various forms of fraud and violence, most notably the alleged falsification of results at collation centres, intimidation of voters, arrest and detention of domestic election observers by security agents until after the elections, hijacking and stuffing of ballot boxes, bombings in Kaduna and Borno states, and the electoral violence that attended the declaration of Goodluck Jonathan as the winner. ${ }^{12}$

It is not yet clear how many of the successes of the elections can be attributed to the reform of the electoral process. But for now it is safe to say that the reform process tried to insulate INEC from political influence by guaranteeing its financial

11 See 'Must Win Election: Jonathan Spends 107 Billion in 2 Days, Meets Jega in Private'. Available at: www.nairaland.com/nigeria/topic-647222.0.html; www.nigeriannewsservice.com/nns-news-archive/ lead-stories / must-win-election-jonathan-spends-n107-billion-in-two-days

12 The northern part of the country was deeply engulfed in post-election violence following the declaration of President Jonathan as the winner of the election. Many attributed this to a statement credited to General Buhari while casting his vote, that the PDP had airlifted ballot papers to the north with the aim of rigging the election. Many lives were lost and property worth billions of naira destroyed. 
and administrative autonomy to a very large extent. However, the fact that the appointment of its chair is still the exclusive prerogative of the presidency remains a weak link in the reform process, which could be exploited by desperate politicians to undermine the independence of the body.

It can also be argued that there was not enough time for the reconstituted EMB to rectify the administrative and credibility issues that have plagued it over the years. Generalising about the impact of the reform process on INEC, using the administration of the 2011 elections as an example, may, therefore, result in too harsh a judgement, particularly since there is, as yet, no empirical evidence on which to judge.

However, there are sufficient grounds to suggest that the reform process had a positive impact on the electoral landscape in Nigeria. For the first time the electoral body was able to prepare an independent budget and defend it before Parliament rather than having, as in the past, to go cap in hand to the presidency to solicit funds, thereby subjecting INEC to political influence.

Nevertheless, what the 2011 elections reveal is that institutional reengineering without corresponding attitudinal and behavioural reform is not sufficient to ensure effective electoral administration. While institutional designs are important to effective electoral governance the strategic decisions of the political actors at all levels to take advantage of the reform process within legally permissible limits hold an important key to the restoration of credibility and public trust in the electoral processes and outcome.

As the 2011 elections illustrate, the refusal of political actors, including electoral officers, to play according to the rules largely accounted for the corruption and violence that characterised the process. The failure to respect regulations on electoral finance and the media, for example, cannot be blamed on INEC. It does, however, raise questions about the capacity of the electoral institutions to structure the electoral behaviour of political actors in the Nigerian context. By implication, there are still some loopholes in the institutional architecture of the election-related bodies, which tend to undermine their independence and effectiveness.

This finding has some research implications, most notably the need to undertake a comprehensive empirical study to determine how many of the successes and failures of the 2011 elections may be attributed to the electoral reform process by measuring the level of public trust in the electoral institutions, especially INEC and political parties, and in the electoral process and outcomes.

The challenge for the Nigerian researcher, however, remains that of funding. INEC should be able to develop a strong research unit to undertake self-assessment for further improvement of its current scorecard. 


\section{- REFERENCES}

Adebayo, P F \& J Shola Omotola. 2007. 'Public Perception of Nigeria's 2007 General Elections'. Journal of African Elections 6(2), October.

Adejomobi, S. 2007. 'When Votes Do Not Count: The 2007 General Elections in Nigeria'. News from Nordic African Institute, No 2, May.

___ \& M Kehinde. 2007. 'Building Democracy without Democrats?: Political Parties and Threats of Democratic Reversal in Nigeria'. Journal of African Elections 6(2), October.

Agbaje, A \& S Adejumobi. 2006. 'Do Votes Count? The Travail of Electoral Politics in Nigeria'. Africa Development XXXI (3).

Agbo, A. 2010. 'Red card for Mr President. Civil society groups insist that President Umaru Yar'Adua leaves the scene for Acting President Goodluck Jonathan to take full charge'. Tell, 22 March.

Agyeman-Duah, B. 2005. Elections and Electoral Politics in Ghana's Fourth Republic. Critical Perspective 18, CDD-Ghana, July.

Akintunde, K. 2008. 'Furore over Electoral Reform White Paper'. Newswatch, 24 September. Available at: www.newswatchngr.com/index.php?option=com_ content\&task $=$ view\&id $=755 \&$ Itemid $=47$

Anonymous. 2010. 'Obasanjo's Retort and the Death of Imagination'. Available at: www.nigeriavillagesquare.com/articles/ adebowale-oriku / obasanjosretort-and-the-death-of-imagination.html

Berinsky, A J. 2005. 'The Perverse Consequences of Electoral Reform in the United States'. American Politics Research 33(4), July.

Birch, S. 2008. 'Electoral institutions and popular confidence in electoral processes: A cross-national analysis'. Electoral Studies 27(1).

Browne, O. 2004. 'The Electoral Machine: The Bureaucracy and the Electoral Process in the Making of Nigeria's Fourth Republic'. In L Olurode \& $\mathrm{R}$ Anifowose (eds). Issues in Nigeria's 1999 General Elections. Lagos: John West and Rebonik Publications.

Diamond, L. 2008. The Spirit of Democracy: The Struggle to Build Free Society Throughout the World. New York: Times Books.

Elklit, J. 1999. 'Electoral Institutional Change and Democratisation: You can Lead a Horse to the Water, But you Cannot Make it Drink'. Democratisation 6(4), pp 28-51.

___ \& P Svensson. 1997. 'What Makes Elections Free and Fair?'. Journal of Democracy 8(3).

\& A Reynolds. 2002. 'The Impact of Election Administration on the Legitimacy of Emerging Democracies: A New Comparative Politics Research Agenda'. Commonwealth and Comparative Politics 40(2). 
Green, D P \& A S Gerber. 2004. Get out the Vote: How to Increase Voter Turnout. Washington, DC: Brooking Institution Press.

Hartlyn, J, J McCoy \& T M Mustillo. 2008. 'Electoral Governance Matters:

Explaining the Quality of Elections in Contemporary Latin America'. Comparative Political Studies 41(1).

Hooghe, M, B Maddens \& J Noppe. 2005. ‘Why Parties Adapt: Electoral Reform,

Party Finance and Party Strategy in Belgium. Electoral Studies 25(2).

Ibrahim, J. 2007. Nigeria's 2007 Elections: The Fitful Path to Democratic Citizenship. Special Report No 182, January. Washington, DC: United States Institute of Peace.

IFES. 2009. 'Electoral Reform in Nigeria: "Business as Usual" Throttles Hopes'. Available at: www.ifes.org/Content/Publications / Opinions / 2009 / Apr / Electoral-Reform-in-Nigeria-Business-as-Usual-Throttles-Hope.aspx

International IDEA. 2006. Electoral Management Design: the International IDEA Handbook. Stockholm: International IDEA.

Iwu, M. 2008. The April 2007 Elections in Nigeria: What Went Right? Ibadan:

Department of Political Science, University of Ibadan, April.

Johnson, R, D Rossiter \& C Pattie. 2006. 'Changing the Scale and Changing the Result: Evaluating the Impact of Electoral Reform on the 2000 and 2004 US Presidential Elections. Political Geography 25.

Kew, D. 2010. 'Nigerian Elections and the Neopatrimonial Paradox: In Search of the Social Contract'. Journal of Contemporary African Studies 28(4).

Lawal, K. 2007. 'Elections: Courts Receive 6,180 Cases'. The Herald, Ilorin, 12 May.

Mozaffar, S. 2002. 'Patterns of Electoral Governance in Africa's Emerging Democracies'. International Political Science Review 23 (1).

__ \& A Schedler. 2002. 'The Comparative Study of Electoral Governance Introduction'. International Political Science Review 23 (1).

National Democratic Institute. 2007. 'This is Not the Will of Nigerians'. Text of a report of the NDI, a Washington-based organisation led by Madeleine Albright, former US Secretary of State, on the 2007 Nigerian Election.

Nwosu, H. 2008. Laying the Foundation for Nigeria's Democracy: My Account of June 12, 1993 Presidential Election and its Annulment. Lagos: Macmillan.

Oguntola, S. 2010. ‘Obasanjo Blasphemed Jesus, Say Okonkwo, Osu, Others'. The Nation, 2 May. Available at: thenationonlineng.net/web2/articles / 45061/1/ Obasanjo-blasphemed-Jesus-says-Okonkwo-Osu-others-/ Page1.html

Omotola, J S. 2009a. "“Garrison” Democracy in Nigeria: The 2007 General Elections and the Prospects of Democratic Consolidation'. Commonwealth and Comparative Politics 47(2). 
-_-_. 2009b. 'Ghana Defies the Odds Again: The 2008 Elections and the Consolidation of Democracy. Politeia 29(1).

-_- 2009c. 'Nigerian Parties and Political Ideology'. Journal of Alternative Perspectives in the Social Sciences 1(3).

_ 2010a. 'Elections and Democratic Transitions in Nigeria under the Fourth Republic'. African Affairs 109(437).

_ 2010b. 'Political Parties and the Quest for Political Stability in Nigeria'. Taiwan Journal of Democracy 6(2).

—_. 2010c. 'Explaining Electoral Violence in Africa's "New" Democracies'. African Journal on Conflict Resolution 10(2).

—_. 2011. 'A Cabalised Regime: Neopatrimonialism, President Yar'Adua's Health Crisis and Nigeria's Democracy'. CEU Political Science Journal 6(2).

Osun Defender. 2011. '2011 Presidential Poll Most Systematically Rigged', 21 April. Available at: www.osundefender.org/? $\mathrm{p}=15421$

Pastor, R A. 1999. 'The Role of Electoral Administration in Democratic Transitions: Implications for Policy and Research'. Democratisation 6(4).

Rigby, E \& M J Springer. 2001. 'Does Electoral Reform Increase or (Decrease) Political Equality?' Political Research Quarterly 64(2).

Stein, R, C Owens \& J Leighley. 2003. 'Electoral Reform, Party Mobilization and Voter Turnout'. Paper presented at the Annual Meeting of the Midwest Political Science Association, Chicago IL.

Tell. 2007. 'Nigeria: Failed Elections, Failing State?' Executive Summary and Recommendation of the International Crisis Group on the 2007 Nigerian Elections, 30 May. Dakar/Brussels. Available at: www.crisisgroup.org/ home/index.cfm?id=4876.

Tide, The. 2011. '2011: INEC Composition May Shortchange Nigerians'. Available at: www.thetidenewsonline.com/? $\mathrm{p}=10827$.

Week, The. 2007. 'April Polls Fallout: Untold Story of Fraud', 14 May. —_ 2007. 'Controversial Polls': Why the System Failed', 17 May.

Yar'Adua, U. 2007. Presidential Address at The Electoral Committee's Inauguration Ceremony. Available at: electoralreformsng.org/speech.php 